\title{
CORRESPONDENCE
}

\section{Conferences in Russia?}

SIR,-Two events occurred this summer which, taken together, should be of particular concern to geneticists, as well as many other scientists. On July 16 the Supreme Soviet deprived Dr Zhores Medvedev of his Soviet citizenship, thus preventing his return from Britain to the USSR. On August 23 it was announced at the 13th International Congress of Genetics at Berkeley, California, that the International Genetics Federation had recommended that the next International Congress should be held in Moscow in five years time.

Dr Medvedev's reputation is based both on his scientific research and his courageous attempts to expose some of the defects in the organisation of science in the Soviet Union. His sole purpose throughout has been to help eradicate these defects. One of his books ${ }^{1}$ provides a detailed history of the Lysenko period, when a deliberate and systematic attempt was made to kill the science of genetics. This book has not been published in the Soviet Union, and many supporters of Lysenko still hold influential positions in biology. Another book $^{2}$ deals with the difficulties he and other Soviet scientists have had in trying to communicate with or visit their colleagues in other countries, and with the problems of censorship. This book has not been published in the Soviet Union either, and there is every indication that the situation is now worse than it was when Dr Medvedev described it in 1970. By publishing these books in the West, he has brought to light facts which are unpalatable to the Soviet government, and it is certainly for this reason that he was deprived of his citizenship.

Scientists should support Dr Medvedev in his struggle to break down the barriers to communication, but they should not assume that attending meetings or congresses within the Soviet Union necessarily provides such support. It is essential to realise the hypocrisy of the official Soviet attitude to free exchange of scientific ideas and information. In effect, the Soviet Union has for many years imposed a boycott on numerous scientific meetings or conferences outside Eastern Europe. Anyone who has organised conferences in the West and has invited a Soviet scientist to participate knows that the invitation will often be either refused or ignored. If it is accepted, in most cases the scientist does not in fact come to the conference. In many instances this has caused considerable confusion and has prevented some other well qualified scientists from participating.

Under these circumstances, why should one take seriously the attempt by the Soviet organisers to bring about exchange of information between scientists at an international congress in Moscow? Furthermore, why should other Genetical Societies collaborate with the Society organising the Moscow congress (N. I. 'Vavilov's All-Union Scientific Society of Genetics and Selection) when that body has not protested against the exile of one of its best known members, who has done so much to reinstate genetics as a real science in the Soviet Union?

I believe that geneticists should attend the congress in Moscow only if the following conditions are fulfilled. (1) The Academy of Science of the USSR must guarantee that there will be no restriction to participation on political or any other non-scientific grounds. (Unfortunately the verbal statement to this effect by the Soviet delegate at the International Federation meeting at Berkeley is not an adequate assurance.)

(2) There must be some evidence within the next few years that Soviet scientists who are invited to conferences in the West will be allowed to attend. (3) $\mathrm{Dr}$ Medvedev's citizenship must be restored.

Following the decision at Berkeley, I think it is very important to find out whether geneticists in countries outside the Soviet Union share or disagree with my point of view, and I would therefore welcome letters which express a clear opinion on this matter.

Finally, I must make it absolutely clear that although Dr Medvedev and I are collaborating in ageing research in the Genetics Division of this Institute, this letter was written entirely on my own initiative, and he is in no way responsible for any part of it.

\section{Yours faithfully,}

\section{RoBIN HOLLIDAY}

National Institute for Medical Research, The Ridgeway,

Mill Hill, London NW7 $1 \mathrm{AA}$

${ }^{1}$ Medvedev, Zh. A., The Rise and Fall of T. D. Lysenko, trans. by Prof. I. M. Lerner (Columbia University Press, New York, 1969).

2 Medvedev, Zh. A., The Medvedev Papers, trans. by Vera Rich (Macmillan, London, 1971).
OuR correspondent, W. H. McC., writes:

SIR,- - In the London telephone directory there are some tens of thousands of entries having the first initial $\mathrm{H}$ and a similar number having a second initial $W$, and there are over a hundred entries with the name Davenport. There is, however, as it happens, precisely one H. W. Davenport. Here, for the satisfaction of the $\mathrm{H}$. W. Davenport who wrote (from Michigan unfortunately) the letter you published in Nature (245, $111 ; 1973)$ is a case where "three doubts make a truth".

In the sentence he quotes from my notice, as I had stated, "item" has a technical meaning assigned by Sturrock in the work I was reviewing. So the quoted sentence has a more sophisticated significance than appears when it is taken out of context. Nevertheless the result is basically the same as the probability of identifying someone by name and initials. I did, in fact, comment that the result was expected but that Sturrock's quantitative illustration was highly interesting.

\section{Paperback Polymorphism}

SIR,-I find to my astonishment that I have three copies of the Dover paperback edition of $\mathrm{R}$. A. Fisher's The Genetical Theory of Natural Selection. The books are identical in every respect except that the cover of one is green another red, and the third grey-colours which contrast conspicuously and which perhaps are responsible for my having inadvertently bought three copies. Fisher himself was deeply interested in the theory of genetic polymorphism, and no doubt would have been delighted to hear that the polymorphism in the paperback edition of his classic work had possibly affected its sales. It would be interesting to know if by producing the same book with different coloured covers affects the search image of a potential purchaser in such a way as to increase sales.

Yours faithfully,

D. F. OWEN

Department of Animal Ecology,

University of Lund,

Ecology Building, S-22362 Lund

\section{Anomalous Water}

SIR,--The note on the 'Nature of "Anomalous Water", by B. V. Derjaguin and N. V. Churaev ${ }^{1}$ is not con- 